\section{Polymorphism of mtDNA Cytochrome b Gene of Local Cattle in Indonesia}

\author{
T.Hartatik $^{\mathrm{a} *}$, W.B.P. Putra ${ }^{\mathrm{ab}}$, \\ S.D.Volkandari ${ }^{\mathrm{a}}$, and Sumadi ${ }^{\mathrm{a}}$
}

\begin{abstract}
${ }^{a}$ Laboratory of Animal Breeding, Faculty of Animal Science, Universitas Gadjah Mada, Yogyakarta 55281, Indonesia

${ }^{b}$ Graduate student of Master Program in Animal Sciences, Faculty of Animal Science, Universitas Gadjah Mada, Yogyakarta 55281, Indonesia
\end{abstract}

\section{Received: January 27, 2015/ Accepted: April 24, 2015}

\section{Abstract}

The aim of this study was to evaluate of genetic diversity of local cattle in Indonesia. We analyzed the polymorphism of mtDNA cytochrome b (cytb) gene using Polymerase Chain Reaction-Restriction Fragment Length Polymorphism (PCR-RFLP) method. Seventy-three Indonesian local cattle were used in the study that consisted of Madura cattle from Madura island $(n=15)$, Madura cattle from Sapudi island $(n=23)$, Limousin $x$ Madura from Madura island $(\mathrm{n}=5)$, Bali cattle from Kupang ( $(n=12)$, Aceh cattle from Aceh $(n=5)$, Pesisir cattle $(n=4)$, Bali cattle from West Sumatera $(n=1)$, and Java cattle from Pacitan $(n=8)$. The 464-bp fragment of cytochrome b (cyt b) gene was amplified using primers: forward primer of L14735 and reverse primer of H15149. The PCR product was digested using HinfI and TaqI restriction enzyme to identify the polymorphism of mtDNA cytochrome b (cytb) gene. The result showed that there was two haplotypes (A and B). Aceh and Pesisir cattle have $100 \%$ haplotype B meanwhile Bali cattle (from Kupang and West Sumatera) and Limura cattle have $100 \%$ haplotype A. Whereas, Madura cattle from Madura and Sapudi island and Java cattle have two different haplotypes (A and B). There was mt-DNA cytochrome b polymorphism of local cattle in Indonesia based on PCRRFLP analysis method. Since the genetic variation in local cattle showed the differences in the specific area, it is necessary to control the cattle populations based on the species.

Keywords: Polymorphism; genetic variation; cytochrome b gene; local cattle; Indonesia

\footnotetext{
* Corresponding author. Tel.:+62-274-4333373; fax:+62-274-521578. E-mail address:tetyharuta@yahoo.com
}

Abbreviations:
\begin{tabular}{|lll|}
\hline PCR-RFLP & $:$ & Polymerase Chain Reaction-Restriction \\
& & Fragment Length Polymorphism \\
MtDNA & $:$ & Mitochondrial Deoxinucleid acid \\
Cyt b & $:$ & Cytochrome b \\
\hline
\end{tabular}

\section{Introduction}

Domestic cattle in East and Southeast Asia are believed to have originated from three ancestral groups, namely, European cattle (Bos taurus), Zebu cattle (Bos indicus) and Bali cattle (Bos javanicus, the descendant of Bos banteng) [1]. Indonesia have several of domestic cattle breed such as Madura cattle, Bali cattle, Aceh cattle, Pesisir cattle, Java cattle, etc that spread in several island. Mitochondrial DNA analysis can be used looking for genetic diversity on population. Mitochondrial DNA (mtDNA) is maternally inherited and changes in the nucleotide sequence occur faster than nuclear DNA [2] so mtDNA is ideally suited as a tool for studying population genetics [3]. Mitochondrial DNA (mtDNA) is a useful genetic marker for both intraand interspecies studies $[4,1]$. Several studies on mtDNA RFLP of cattle have been reported. According to previous studies [1], there are three major groups of domestic cattle in East and Southeast Asia: European cattle, Zebu cattle and Bali cattle. Each of the three groups has mtDNA with a specific haplotype. Ancestral populations of Asiatic domestic cattle may have diverged into two lineages - Bali and European plus Zebu. Five haplotypes were defined by mtDNA restriction fragment length polymorphism (RFLP) in 11 indigenous cattle breeds and one cultivated breed in South China, in which haplotype I, II, and III were identical to the zebu, taurine and yak (Bos grunniens), respectively [5]. Therefore, mtDNA RFLP is a useful system for studying genetic variation in local cattle of Indonesia. The objective of the present study was to evaluate of genetic diversity of local cattle in Indonesia.

\section{Materals and Methods}

\subsection{Samples}

Seventy-three Indonesia local cattle were used in the study that consisted of Bali cattle from Kupang $(n=12)$, Aceh cattle from Aceh $(n=5)$, Pesisir cattle $(n=4)$, Bali cattle from West Sumatera $(n=1)$, and Java cattle from Pacitan ( $=8$ ). In this study used Madura cattle from Madura island $(\mathrm{n}=15)$, Madura cattle from Sapudi island $(\mathrm{n}=38)$, Limousin $\mathrm{x}$ Madura (Limura) cattle from Madura island ( $\mathrm{n}$ 
= 5) [6] as a comparison. Blood samples were collected from all animals by jugular vein that was saved in tubes containing $\mathrm{K}_{3}$ EDTA and stored at $-20^{\circ} \mathrm{C}$ until DNA extraction.

\subsection{DNA extraction}

Genomic DNA was isolated from whole blood by using standard SDS/ProteinaseK method according to Sambrook el.al.[7]. A $200 \mu \mathrm{l}$ of whole blood was moved to a $1.5 \mathrm{ml}$ tube and added buffer A $800 \mu$ then centrifuge 6000 rpm for 5 minute. Carefully discard upper liquid, then add buffer A $300 \mu \mathrm{l}$ and repeat again centrifuge 6000 rpm for 5 minute. Carefully discard upper liquid, add buffer B $270 \mu \mathrm{l}$ and buffer $C 30 \mu l$. Incubate for overnight at $50^{\circ} \mathrm{C}$ in multi heater. Add $71 \mu \mathrm{l}$ of saturated $5 \mathrm{M} \mathrm{NaCl}$ and strongly shake 15 sec. Centrifuge at 6000 rpm for 10 minutes take out and place the upper liquid to new tube. Precipitate the DNA using 2 volume absolute $\mathrm{EtOH}$ at the room temperature. Centrifuge at $12.000 \mathrm{rpm}$ for 10 minutes then discard the upper liquid. Wash the DNA using $70 \% \mathrm{EtOH}$ and centrifuge at 12.000 rpm for 5 minute. Discard upper liquid and drying at room temperature and dissolved in TE buffer or sterile aquabidest $100 \mu \mathrm{l}$. The extracted DNA samples were stored at $-20{ }^{\circ} \mathrm{C}$ and used later as a substrate for PCR reaction.

\subsection{Polymerase Chain Reaction (PCR)}

The 464-bp fragment of cytochrome b (cyt b) gene was amplified using primers: forward primer of L14735 (5'-AAA AAC CAC CGT TGT TAT TCA ACT-3') and reverse primer of H15149 (5'-GCC CCT CAG AAT GAT ATT TGT CCT CA3) [8]. DNA was amplified in a total volume of $20 \mu \mathrm{l}$ containing $1 \mu \mathrm{l}$ genomic DNA (10-10o ng), $1 \mu \mathrm{l}$ each primers, 1o $\mu$ l PCR KIT (KAPPA2GTM Fast, KAPABIOSYSTEMS, USA) and $7 \mu$ aquabidest sterile. PCR conditions were 2 min at $94^{\circ} \mathrm{C}, 36$ sec at $95^{\circ} \mathrm{C}, 73 \mathrm{sec}$ at $51^{\circ} \mathrm{C}, 84$ sec at $72^{\circ} \mathrm{C}, 35$ cycles and $3 \mathrm{~min}$ at $72^{\circ} \mathrm{C}$ [9]. The PCR was carried out in Primus-25 Advanced (Germany) Thermal Cycler. The PCR products were visualized on $1 \%$ agarose gel buffered with IX Tris-Boric-EDTA buffer (IXTBE), stained with ethidium bromide and visualized under UV light.

\subsection{Restriction Fragment Length Polymorphism (RFLP) and haplotype}

The PCR-amplified DNA fragment of the cytochrome $b$ was digested using HinfI and TaqI restriction enzyme to identify of genetic pattern. Total volume of digestion was $20 \mu \mathrm{l}$ containing 10 $\mu \mathrm{l}$ PCR product, $0.3 \mu \mathrm{l}$ HinfI (Fermentas) or TaqI (Fermentas) enzyme (iU), $2 \mu \mathrm{l}$ Tango buffer and $7.7 \mu$ laquabidest steril. The PCR product was digested at $37^{\circ} \mathrm{C}$ for three hours by Hinfl enzyme and at $65^{\circ} \mathrm{C}$ for two hours by TaqI enzyme. The digestion products were separated on $2.5 \%$ agarose gels in 1 XTBE buffer and run with $50 \mathrm{~V}$ for an hour for separation of the DNA fragments. The bands were stained with ethidium bromide to visualization by UV light. The size of the DNA fragments were compared with DNA marker $\phi \mathrm{X}_{174}$ DNA/BsuRI (HaeIII) (Fermentas).

\subsection{Sequencing analysis}

Two samples represent the haplotype were sequenced in order to understand the single nucleotide polymorphisms (SNPs). Total volume $30 \mu \mathrm{l}$ of PCR product from each sample was send to ist Base Genetika Science for further sequencing. Then the sequence results were analyzed using Bioedit 7.7 to determine the restriction mapping and SNPs.

\section{Results and Discussion}

The results of the study showed that there were two haplotypes (A and B). Using Hinfl enzyme as a restriction enzyme, haplotype $A$ showed three bands with the DNA fragment size 198, 149, and $117 \mathrm{bp}$, where the haplotype B showed two bands with DNA fragment size 305 and 159 bp (Fig.1). In the other site, by using TaqI restriction enzyme, haplotype A showed two bands with the DNA fragment size 416 and $48 \mathrm{bp}$, but haplotype B showed three bands with the DNA fragment size 225, 191 and 48 bp (Fig.2). Based on Table 1, Aceh and Pesisir cattle have 100\% haplotype B meanwhile Bali cattle (from Kupang and West Sumatera) and Limura cattle have $100 \%$ haplotype A. Whereas, Madura cattle from Madura and Sapudi island and Java cattle have two different haplotypes (A and B).

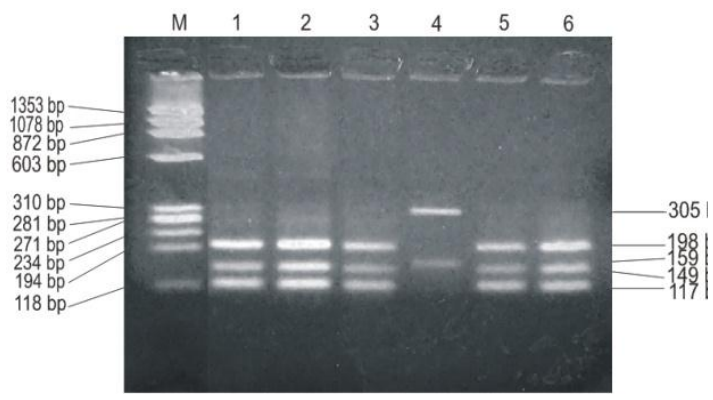

Figure 1 Restriction pattern of Hinfl enzyme. M: Marker $\Phi \mathrm{X}_{174}$ DNA/BsuRI (HaeIII), line 1,2,3,5,6 : Haplotype A and line 4: Haplotype B.

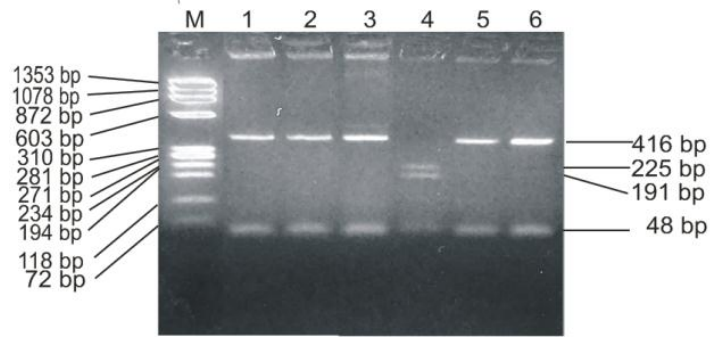

Figure 2 Restriction pattern of TaqI enzyme. M: Marker $\phi \mathrm{X}_{174}$ DNA/BsuRI (HaeIII), line 1,2,3,5,6 : Haplotype A and line 4: Haplotype B. 
The result indicated that Aceh and Pesisir cattle have the same maternal lineage. According to the previous research by Prado et.al [10], Aceh and Pesisir cattle have mitochondrial DNA of zebu. So, Aceh and Pesisir cattle with haplotype B was suspected to related to Bos indicus meanwhile, Bali cattle, Java cattle and Limura cattle with haplotype A was suspected to maternally related to Banteng. Limura cattle were established from the crossing of Madura cattle and Limousin bull by artificial insemination. DNA analysis for Madura cattle from Madura and Sapudi island and Java cattle from Pacitan have two different haplotype (A and B) but haplotype A higher than haplotype B (Table 1). It showed that Madura cattle and Java cattle related mostly to Bos banteng. Limura cattle only show the one haplotype A might be due to the size of sample number. According to the previous research by Prado et.al [10] that DNA analysis of Madura cattle showed that a combination of a zebu paternal lineage with a mixed zebu-banteng maternal origin, so this result give more evidence that Madura cattle has mixed blood from zebu and banteng. Based on Nei genetic distances in a Neighbour Network, Indonesian Aceh, Pesisir, and Filial Ongole are close to the Indian zebu breeds, but they are intermediate between Indian zebu and Bali cattle. Madura and Galekan cattle, several of which carry banteng mitochondria, are more distant from the Indian zebu and closer to Bali cattle. The previous research, the banteng mitochondrial type was found in Bali cattle $[10,11]$.

Table 1 Haplotype frequencies on several breeds

\begin{tabular}{|c|c|c|c|c|c|c|}
\hline \multirow{2}{*}{ Breed } & \multirow{2}{*}{ Location } & \multirow{2}{*}{$\mathbf{n}$} & \multicolumn{2}{|c|}{ Haplotypes } & \multicolumn{2}{|c|}{$\begin{array}{c}\text { Haplotypes } \\
(\%)\end{array}$} \\
\hline & & & A & B & A & B \\
\hline $\begin{array}{l}\text { Madura } \\
\text { cattle [6] }\end{array}$ & $\begin{array}{l}\text { Madura } \\
\text { island }\end{array}$ & 15 & 13 & 2 & 86.67 & $13 \cdot 33$ \\
\hline $\begin{array}{l}\text { Madura } \\
\text { cattle [6] }\end{array}$ & Sapudi island & 23 & 16 & 7 & 69.57 & 30.47 \\
\hline $\begin{array}{l}\text { Limura } \\
\text { cattle [6] }\end{array}$ & $\begin{array}{l}\text { Madura } \\
\text { island }\end{array}$ & 5 & 5 & - & 100 & - \\
\hline Bali cattle & Kupang & 12 & 12 & - & 100 & - \\
\hline Bali & $\begin{array}{l}\text { West } \\
\text { Sumatera }\end{array}$ & 1 & 1 & - & 100 & - \\
\hline $\begin{array}{l}\text { Aceh } \\
\text { cattle }\end{array}$ & Aceh & 5 & - & 5 & - & 100 \\
\hline $\begin{array}{l}\text { Pesisir } \\
\text { cattle }\end{array}$ & $\begin{array}{l}\text { West } \\
\text { Sumatera }\end{array}$ & 4 & - & 4 & - & 100 \\
\hline Java cattle & Pacitan & 8 & 5 & 3 & 62.5 & 37.5 \\
\hline
\end{tabular}

\begin{tabular}{llllll}
\hline Total & 73 & 52 & 21 & 71.23 & 28.77 \\
\hline
\end{tabular}

Table 2 Restriction mapping of individual haplotype A dan B.

\begin{tabular}{ccccc}
$\begin{array}{c}\text { Haplotyp } \\
\text { e }\end{array}$ & $\begin{array}{c}\text { Enzym } \\
\text { e }\end{array}$ & $\begin{array}{c}\text { Recognitio } \\
\text { n sequence }\end{array}$ & $\begin{array}{c}\text { Frequenc } \\
\text { y }\end{array}$ & $\begin{array}{c}\text { Position } \\
\text { s }\end{array}$ \\
\hline A & Hinf & G'AnT_C & 2 & $120 ; 237$ \\
B & TaqI & T'CG_A & 2 & $20 ; 63$ \\
& Hinf & G'AnT_C & 1 & 130 \\
& TaqI & T'CG_A & 2 & $20 ; 244$ \\
\hline
\end{tabular}

Haplotype A

Hinf 1 at position 120

G G A A T C IGCC TA 130 TCC TACAAA I C

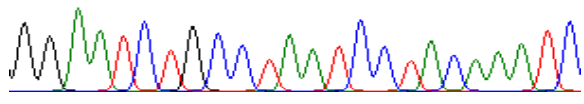

\section{Hinf 1 at position 237}

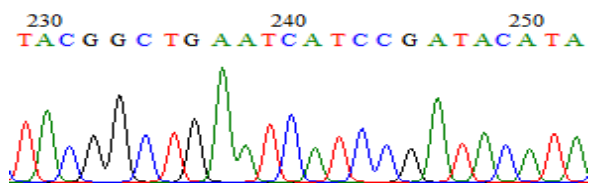

\section{Hinf 1 at position 130}

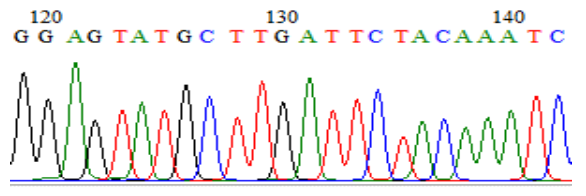

A Aligment A/B

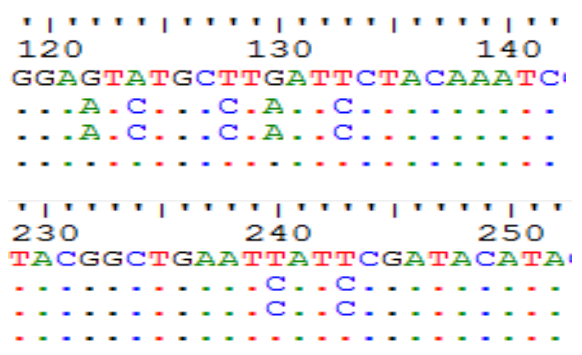

Figure 3 Restriction mapping of HinfI (G'ANT_C) at position 120, 130 and $237 \mathrm{bp}$ 
Restriction mapping of the individual haplotype A and haplotype B (Table 2) show the differences in both position of restriction site and the frequency of cutting site. The data was consistent with the Fig.1 and Fig. 2 as a result of PCR-RFLP. The PCR-RFLP method is very simple and easy. Among the positions of restriction enzymes (4 positions in haplotype $\mathrm{A}$ and 3 positions in haplotype $\mathrm{B}$ ), only one site restriction of TaqI has the same position of restriction site. Therefore we found three SNPs in HinfI site restriction and two SNPs in Taq I site restriction. Total number SNP base on restriction site is five SNPs. The five SNPs based on restriction site position were found independently at difference location. Three SNPs in HinfI site restriction show the specific sequence recognition of haplotype $A$ (G'AAT_C) and that of haplotype B (G'ATT_C) as describe at Fig.3. According to PCR-RFLP method we recognized three SNPs with two different sequences. However alignment sequencing analysis method found the five SNPs from 118-141 nucleotides and two SNPs from 229-252 nucleotides. These SNPs are useful as molecular genetic markers.

\section{Conclusion}

There was mt-DNA cytochrome b polymorphism of local cattle in Indonesia based on PCR-RFLP analysis that indicate two haplotypes (A and B). Since the genetic variation in local cattle showed the differences in the specific area, it is necessary to control the cattle population based on the species. By using molecular marker HinfI and TaqI restriction enzymes the differentiation of specific species can be done easier and quicker. Thus sustainability of genetic resources in local cattle can be maintained for the future prosperity.

\section{Acknowledgment}

This research was partly supported by Post Graduate Grant from Faculty of Animal Science Universitas Gadjah Mada Academic Year 2013/2014. Thank you to Dino Eka Putra, and Arnold C.H. Tabun for their contribution in blood sample collection and DNA extraction of Pesisir cattle and Bali cattle. We also would like to thank to all staff at the Breeding Station of Aceh cattle, staff at Livestock Bureau in Madura, Kupang, Padang, and Pacitan for the nice collaboration and their helping in sample collection.

\section{References}

[1] Kikkawa, Yoshiaki., Takashi Amano, anf Hitoshi Suzuki. 1995. Analysis of Genetic Diversity of Domestic Cattle in East and Southeast Asia in Terms of Variations in Restriction Sites and Sequences of Mitochondrial DNA. Biochemical Genetics, Vol. 33, Nos.1 / 2 , 1995

[2] Brown, W.M. 1980. Polymorphism in mitochondrial DNA of human as revealed by restriction endonuclease analysis.
Proc.Natl. Acad. Sci. USA. Vol. 77, No.6, pp. 3605-3609, June 1980

[3] Bailey, J.F., B.Healy, H.Jianlin, L. Sherchand, S.L.Pradhan, T.Tsendsuren, J.M. Foggin, C.Gaillard, D.Steane, I.Zakharov and D.G.Bradley. 2000. Genetic variation of mitochondrial DNA within domestic yak populations. Proceeding of the third international congress on yak. Lhasa P.R. China, 4-9 September 2000.

[4] Brown, Wesley M., Matthew George, JR and Allan C. Wilson. 1979. Rapid evolution of animal mitochondrial DNA. Proc. Natl. Acad. Sci. USA. Vol. 76, No. 4, pp. 1967-1971, April 1979.

[5] Yu, Y., L.Nie, Z-Q. He, J-K. Wen, C-S. Jian and Y-P. Zhang. 1999. Mitochondrial DNA variation in cattle of South China: origin and introgression. Animal Genetics, 30, 245-250.

[6] Hartatik, T., S.D.Volkandari, Sumadi and Widodo. The Application of Polymerase Chain Reaction-Restriction Fragment Polymorphisms (PCR-RFLP) to Determine Genetic Diversity of Madura Cattle in Sapudi Island. Indonesian Journal of Biotechnology, June 2013, Vol. 18, No.1, pp.70-74.

[7] Sambrook, J., E. F Fritsch, and T. Maniatis. 1989. Molecular Cloning, A Laboratory Manual. Cold Spring Harbour Laboratory Press: Cold Spring Harbour, USA.

[8]. Wolf, C., Rentsch, J., and Hubner, P. 1999. PCR-RFLP Analysis of Mitochondrial DNA: A Reliable Method for Species Identification. J. Agric. Food. Chem., 47, 1350-1355.

[9] Prado, M., Calo, P., Cepeda, A., and Barros-Velázquez,J. 2005. Genetic evidence of an Asian background in heteroplasmic Iberian cattle (Bos Taurus): Effect on food authentication studies based on polymerase chain reaction-restriction fragment length polymorphism analysis. Electrophoresis, 26, 2918-2926.

[10] Mohamad K., M. Olsson, H. T. A. va Tol, S. Mikko, B. H. Vlamings, G. Andersson, H. Rodriguez-Martinez, B. Purwantara, R. W. Paling, B. Colwnbrander, and J. A. Lenstra. 2009. On the Origin of Indonesian Cattle. PLoS ONE May 4 (5) e 5490.

[11] Nijman, I.J., M.Otsen, E.LC.Verkaar, C. de Ruijter, E.Hanekamp, J.W.Ochieng, S.Shamshad, J.E.O.Rege, O.Hanotte, M.W.Barwegen, T.Sulawati and J.A.Lenstra. Hybridization of banteng (Bos javanicus) and zebu (Bos indicus) revealed by mitochondrial DNA, satellite DNA, AFLP and microsatellites. Heredity (2003) 90, 10-16. 